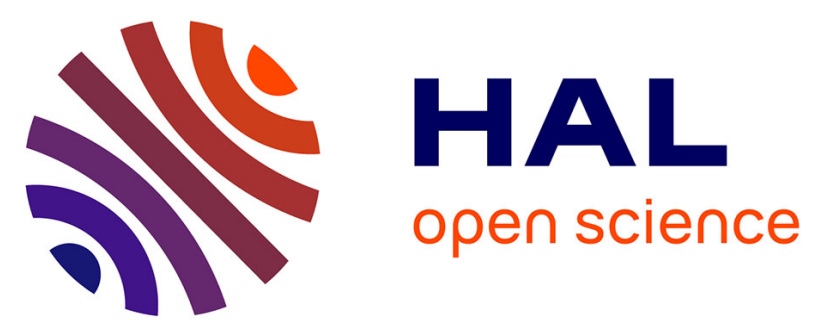

\title{
Impact of a cultivar mixture on scab, powdery mildew and rosy aphid in an organic apple orchard
}

Luciana L. Parisi, Christophe Gros, Freddy Combe, Claude-Eric Parveaud, Christelle Gomez, Laurent Brun

\section{- To cite this version:}

Luciana L. Parisi, Christophe Gros, Freddy Combe, Claude-Eric Parveaud, Christelle Gomez, et al.. Impact of a cultivar mixture on scab, powdery mildew and rosy aphid in an organic apple orchard. Crop Protection, 2013, 43, pp.207-212. 10.1016/j.cropro.2012.09.014 . hal-02647026

\section{HAL Id: hal-02647026 \\ https://hal.inrae.fr/hal-02647026}

Submitted on 29 May 2020

HAL is a multi-disciplinary open access archive for the deposit and dissemination of scientific research documents, whether they are published or not. The documents may come from teaching and research institutions in France or abroad, or from public or private research centers.
L'archive ouverte pluridisciplinaire HAL, est destinée au dépôt et à la diffusion de documents scientifiques de niveau recherche, publiés ou non, émanant des établissements d'enseignement et de recherche français ou étrangers, des laboratoires publics ou privés. 


\title{
Impact of a cultivar mixture on scab, powdery mildew and rosy aphid in an organic apple orchard
}

\author{
Luciana Parisi $^{\mathrm{a}, *}$, Christophe Gros ${ }^{\mathrm{a}}$, Freddy Combe ${ }^{\mathrm{a}}$, Claude-Eric Parveaud ${ }^{\mathrm{b}}$, Christelle Gomez ${ }^{\mathrm{b}}$, \\ Laurent Brun ${ }^{a}$ \\ a INRA, UERI, Domaine de Gotheron, 26320 Saint-Marcel-lès-Valence, France \\ ${ }^{\mathrm{b}} \mathrm{GRAB}$, Domaine de Gotheron, 26320 Saint-Marcel-lès-Valence, France
}

Keywords:

Organic apple production

Cultivar mixtures

Sanitation practices

Fungal diseases

Rosy aphid

\begin{abstract}
A B S T R A C T
The impact of a cultivar mixture within the rows including the cvs Melrouge (low susceptibility to scab) and Pitchounette (Rvi6 resistant) was assessed during 2008-2009 in an organic apple orchard located in Rhône Valley (Drôme, France), on three important pests and diseases: scab, powdery mildew and rosy apple aphid. In this area, the resistance of Rvi6 gene was effective since the orchard plantation in 2004. The impact of the cultivar mixture was assessed per se, but also associated with sanitation practices to decrease the primary inoculum of scab and mildew, and compared to disease development on pure stands of Melrouge. The cultivar mixture showed a good efficiency to decrease the scab incidence on leaves and fruits; a significant effect on scab severity was observed in 2009 for the cultivar mixture plus sanitation practices. Our data confirmed the different susceptibility levels of the two cultivars for powdery mildew. Against powdery mildew, a favourable effect of cultivar mixture, at the condition it is associated with sanitation, was observed in case of a moderate level of the disease (2008). For rosy apple aphid, a favourable effect of cultivar mixture was observed on Melrouge in 2008 when Pitchounette has a good resistance level. In the context of organic production, the impact of the cultivar mixture seemed favourable for the control of the three pests and diseases.
\end{abstract}

\section{Introduction}

To control the main apple diseases, scab [Venturia inaequalis (Cooke) G. Wint.] and powdery mildew [Podosphaera leucotricha (Ellis \& Everh.) E.S. Salmon], standard strategies are based on intensive fungicide applications in orchard.

The plantation of scab resistant cultivars is a good mean to decrease the treatments pressure in apple orchards. However, the main resistance gene, named Rvi6, present in the majority of cultivars resistant to scab, is overcome in several European countries (Parisi et al., 2006; Didelot et al., 2009; Bus et al., 2011). This situation induces the obligation to treat intensively the orchards planted with Riv6 resistant cultivars when the virulent strains are present (Didelot et al., 2009; Caffier et al., 2010). In this context, partial resistance to scab could be a good alternative to reduce treatments in orchards (Brun et al., 2008) and could be also a good

\footnotetext{
* Corresponding author. Tel.: +33 4755992 17; fax: +33475 585626 .

E-mail addresses: lparisi@avignon.inra.fr (L. Parisi), laurent.brun@avignon.inra.fr (L. Brun).
}

strategy to provide durable resistance (MacDonald and Linde, 2002). However, this resistance is not able to supply a complete protection. Thus, the implementation of strategies is needed to associate different cultural practices and low-fungicides applications (Brun et al., 2010; Didelot et al., 2010).

Many studies have shown the efficiency of cultivar mixtures for reducing epidemics of aerial pathogens, mainly in cereal crop (Wolfe, 1985; Zhu et al., 2000; Mundt, 2002). In perennial crops, the two main examples concern the control of foliar rusts: the composite coffee cultivar Columbia (Moreno Ruiz and Castillo Zapata, 1990) and clonal mixtures in short rotation coppice of willow in Northern Ireland (McCracken and Dawson, 2003). The effects of cultivars mixtures on pests have rarely been studied. Recently, in banana crop, a positive effect of varietal mixtures on the number and community structure of plant feeding nematodes has been demonstrated (Quénéhervé et al., 2011). In apple, planting cultivar mixtures is a cultural practice that can reduce the epidemics of the fungus V. inaequalis (Bousset et al., 1997; Didelot et al., 2007). Working with a mixture of a scab susceptible cultivar and an Rvi6 resistant one (not overcome), Didelot et al. (2007) showed that cultivar mixture effect was increased by 
Version définitive du manuscrit publiée dans / Final version of the manuscript published in :

Crop Protection (2013), Vol. 43, p. 207-212, DOI: 10.1016/j.cropro.2012.09.014

Journal homepage: http://www.elsevier.com/locate/cropro

moderate chemical treatments. Moreover, the association of an Rvi6 resistant cultivar and a susceptible one is not recommended if the resistance is overcome, as it could favour the pathogen diversity (Trapman, 2006). Thus, it seems more interesting to promote cultivar mixtures between low susceptible and/or resistant cultivars.

Sanitation practices are important for scab control. The objective is to decrease $V$. inaequalis potential of overwintering in the leaf litter in the orchard. Leaf shredding or urea application on leaf litter can reduce ascospore ejections by 50-92\% (Sutton et al., 2000; Vincent et al., 2004). Treatments with fungal antagonists combined or not with leaf shredding and/or urea application allowed an ascospore reduction of 76-96\% (Carisse et al., 1997, 2000; Vincent et al., 2004). In an organic orchard, Gomez et al. (2007) showed that leaf litter removal from the alleys combined with leaf ploughing in within rows allowed to reduce ascospore ejections by $95 \%$ and scab development on leaves and fruits. However, the important rates of ascospore reduction allowed by these techniques cannot provide a decrease of fungicides applications, especially on susceptible cultivars (Sutton et al., 2000).

In this study, we chose to work in an organic orchard because cultivar mixtures could be easier to implement, as the control of scab may be difficult (Simon et al., 2006) and dependant of organic fungicides. This context is also favourable for the plantation of partial resistant cultivars and the promotion of sanitation practices. The first aim of this study is to test the efficiency against scab of a mixture between a low-susceptible and a resistant cultivar associated or not with sanitation; the second aim is to test the consequences of this strategy on another important disease, the powdery mildew, and on a major pest in organic apple (Simon et al., 2006), the rosy apple aphid (Dysaphis plantaginea Pass.).

\section{Materials and methods}

\subsection{The experimental orchard}

The experimental orchard was located in the Middle Rhone Valley, at Saint-Marcel-lès-Valence (Drôme, France), in a continental area with Mediterranean Summer influences. This orchard, planted in 2004, included 2 cultivars grafted on rootstock Pajam ${ }^{\circledR} 2$ (4160) Cepiland. The first, Melrouge, is a mutant of Melrose, old cultivar with a low susceptibility to scab and a moderate susceptibility to powdery mildew (Trillot et al., 2002). Melrouge was planted in pure stands and in a within row mixture with Pitchounette (3318). Pitchounette is a cultivar resistant to scab (Rvi6 gene) and with a low susceptibility to powdery mildew (Combe et al., 2005). The distance between the trees was $1.70 \mathrm{~m}$, between the rows $4 \mathrm{~m}$. The total area of orchard was 0.48 ha, divided in 3 blocks (Fig. 1). Each bloc included a pure stand of Melrouge (Pure), and 2 plots with the mixture (CVM), one of these plots aimed to associate the cultivar mixture with sanitation practices $(\mathrm{CVM}+\mathrm{S})$. To limit the interactions between plots, each plot was surrounded by an edge of evergreen shrubs, and a net separating the CVM $+\mathrm{S}$ plots was added in October 2008 (Fig. 1). The distance was $15 \mathrm{~m}$ between the trees of two plots. The orchard was managed following the French rules of organic production. The experiment was done during 2008 and 2009.

\subsection{Sanitation practices in $C V M+S$ plots}

For powdery mildew sanitation, the manual eradication of infected leaves clusters after bud break was done on 3 April in 2008 and on 9 April in 2009; the infected leaves clusters were counted and integrated in the calculation of primary infection in CVM $+\mathrm{S}$ plots.

For apple scab, to decrease the primary inoculum, the dead leaves on the orchard ground were removed with a lawn sweeper in inter-rows (the alleys) and buried within the row (Gomez et al., 2007) on the 9 November 2007 and 27 November 2008.

\subsection{Potential ascospore dose (PAD) assessment for scab}

The PAD was evaluated in each plot following the Gadoury and Mac Hardy's method (1986), and expressed as a potential number of ascospores of $V$. inaequalis per square metre of orchard floor.

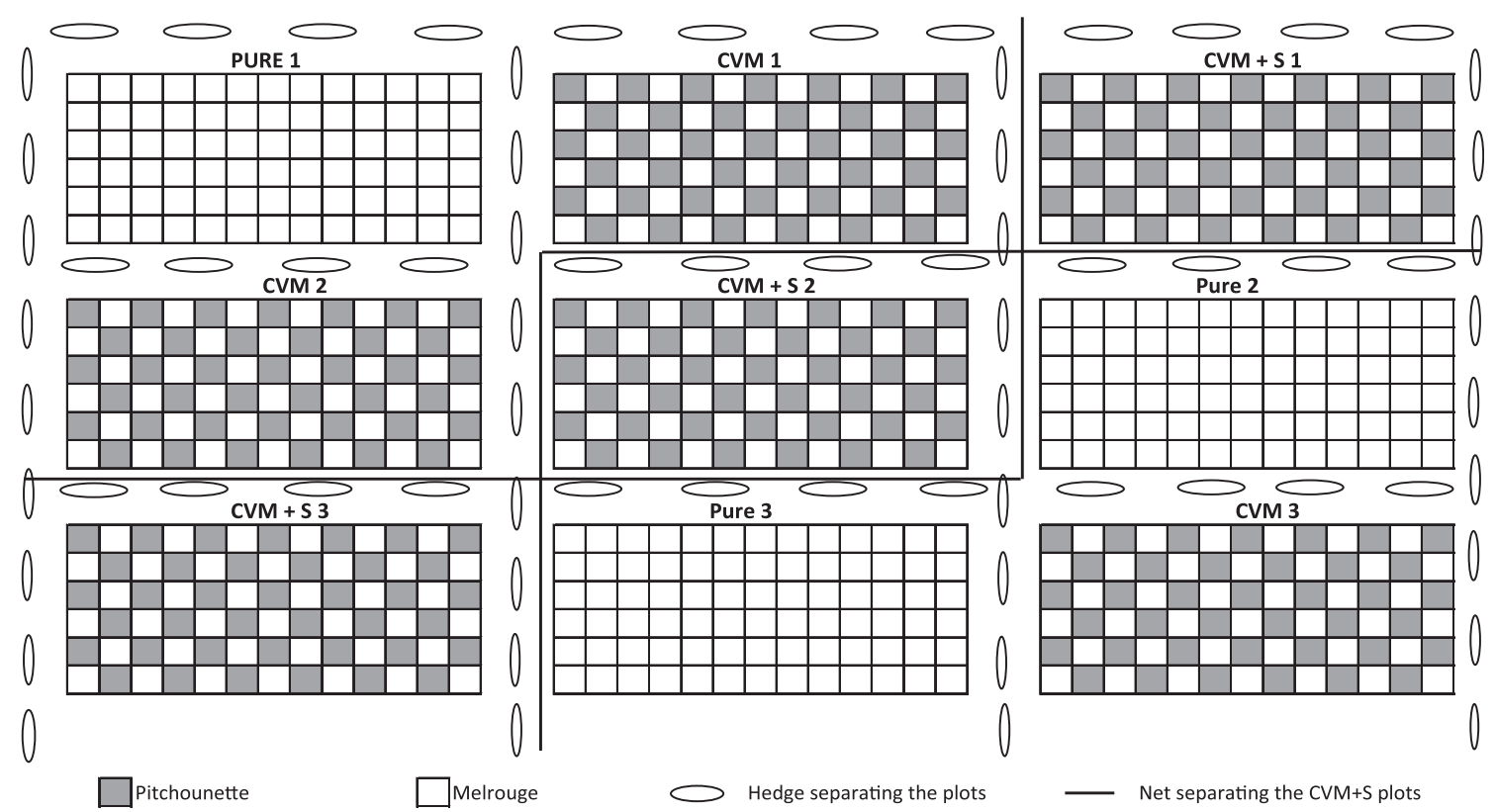

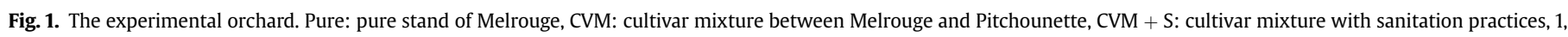
2, 3: number of the blocks. 


\subsection{Estimation of scab infection risks}

The climatic data were recorded by a meteorological station Cimel Enerco 516i from the INRA national network "Agroclim", located on grassland at $900 \mathrm{~m}$ from the orchard. With these data, the climatic risks were evaluated by the software Vintage ${ }^{\circledR}$ (Connecting Nature, Technopole Montesquieu, Martillac, France), based on the "light", "moderate" and "severe" scab infection risks defined by Mills and Laplante (1951), and the very light scab infection risk known as the "Angers" risk (Olivier, 1986).

\subsection{Pest and diseases treatment and assessment}

No treatment against the two major fungal diseases, scab and mildew, was done since the plantation, to permit the development of these diseases for the experimental purpose. Treatments to control rosy aphid were made with mineral oil and rotenone (three treatments in 2008 and 2009), but were not completely efficient; rosy aphids were present the two years in the orchard.

The scab development was measured by several scoring on leaves and fruits (during fruit growth and at picking, on Melrouge, as scab was not present on Pitchounette during all the experiment). On leaves, 80 shoots per plot were scored (2 shoots per tree in opposite directions) and when scab was detected, the number of lesions was assessed. At picking, in 2008, all the fruits per tree were evaluated (with a maximum of 30 fruits), and 20 fruits per tree in 2009. For each plot, shoot scab incidence was defined as the percentage of shoots scabbed, and shoot scab severity as the mean number of scab lesions per shoot. For each plot, fruit scab incidence was defined as the percentage of fruit scabbed, and fruit scab severity as the mean number of scab lesions per scabbed fruits. The area under the disease progress curve (AUDPC) values were calculated from the curve of progression of shoot scab incidence and shoot scab severity in each plot.

Powdery mildew was evaluated for primary infections on the 2 May 2008 and 28 April 2009 on the two cultivars, as the number of shoots with mildew per tree. All trees were sampled. Secondary infections were evaluated on the 1 June 2008 and 18 May 2009 on the two cultivars, as the mean percentage of leaves with mildew. A sample of 40 shoots per plot was determined, symptoms were observed on the 5 youngest full developed leaves per shoot.

On the two cultivars, rosy aphid incidence was evaluated on the 14 May 2008 and 6 May 2009, on 26 trees per plot and two shoots per tree, and expressed as the mean percentage of infested shoots per plot.

\subsection{Statistical analysis}

The PAD, AUDPC of shoot scab incidence and shoot scab severity, fruit incidence and severity at picking, powdery mildew primary and secondary infection, and rosy aphid incidence were subjected to an analysis of variance (ANOVA) to evaluate differences between the Pure stand, CVM and CVM $+\mathrm{S}$. ANOVA were computed using R software (R Development Core Team, 2009) or Statgraphics plus 5.1 software (Manugistics, Rockville, MD, USA). The level of significance was set at $5 \%$ for all the statistical tests. When residual standard deviation increased with the increment of predicted values, data were log transformed before ANOVA (Dagnélie, 1975). Mean comparisons were conducted using the Newman-Keuls test.

\section{Results}

\subsection{Apple scab}

Scab epidemiology was different in the two years: 2008 was a favourable year with 20 infection risks compared to 2009 with only 7 infection risks (Table 1 ). Studying the correlation between PAD and aerial ascospore concentration, Brun et al. (in press) observed interactions between plots in the experimental orchard: dead leaves can move from a plot to another, especially in windy regions like the Rhône Valley. To improve the experimental design and decrease the interaction between plots, a net was placed in October 2008 around the CVM + S plots, providing a physical barrier. So, we have to consider that the efficiency of the cultivar mixture associated with sanitation practices was evaluated correctly only in 2009.

In absence of treatments for scab control, the PAD increased drastically between 2008 and 2009. Compared to the pure stand, the PAD was significantly reduced in the cultivar mixture in 2008 and 2009 . This reduction is much more than $50 \%$ suggesting that it is not the simply effect of the dilution by the leaves from the resistant cultivar. The sanitation practices provided a significant reduction of PAD in CVM + S plots in 2009 (Table 2).

In 2008, despite the 20 climatic risks registered, the disease level was not high (it was the second year of development of disease in this orchard and the primary inoculum was not very high). On July 1 , only $1.7-5.1 \%$ of the shoots were scabbed, and at picking, $7.3-14.9 \%$ of the fruits were scabbed in CVM $+\mathrm{S}$ and pure stand, respectively. In 2008, the incidence of the disease on shoots and fruits was significantly higher on the pure stand than in cultivar mixtures. For the severity of the disease on shoots and fruits, no significant difference was observed (Fig. 2; Table 3).

In 2009, with a high primary inoculum, the level of disease was important: at the end of June, $24.7-28.2 \%$ of the shoots were scabbed, and at picking, 70.5-82.2\% of the fruits were scabbed in $\mathrm{CVM}+\mathrm{S}$ and pure stand, respectively. In this case of a higher level of the disease, no significant difference was observed between the pure stand and the CVM plots (except for fruit incidence). The cultivar mixture has to be associated with sanitation to provide a significant control of the disease: significant difference was found between pure stand and CVM $+\mathrm{S}$ plots for incidence and severity on shoots and fruits (Fig. 2; Table 3).

\subsection{Powdery mildew}

For powdery mildew, the results obtained confirmed the lower susceptibility of Pitchounette compared to Melrouge for secondary infection (Table 4). No significant difference for the powdery mildew primary infection on Melrouge was found between the different modalities (Table 5). For the secondary infection on Melrouge, no significant effect was observed when the level of disease is low (2009), but a significant effect of the mixture was observed in case of higher level of disease (2008) at the condition that it is associated with sanitation (Table 5).

\section{Table 1}

Scab infection risks, according to Mills and Laplante (1951) and Olivier (1986), from bud break to the end of June in the 2 experimental years.

\begin{tabular}{lllll}
\hline \multicolumn{5}{c}{ Scab infection risk } \\
\cline { 2 - 5 } & Angers & Light & Moderate & Severe \\
\hline 2008 & 1 & 11 & 2 & 6 \\
2009 & 0 & 4 & 3 & 0 \\
\hline
\end{tabular}


Version définitive du manuscrit publiée dans / Final version of the manuscript published in :

Crop Protection (2013), Vol. 43, p. 207-212, DOI: 10.1016/j.cropro.2012.09.014

Joyrnal homepage: http://www.elsevier.com/locate/cropro

Table 2

Potential ascospore dose in the pure stand of Melrouge and the two cultivar mixtures in 2008 and 2009.

\begin{tabular}{llr}
\hline & \multicolumn{2}{l}{ Potential ascospore dose ${ }^{\mathrm{a}}$} \\
\cline { 2 - 3 } & $2008^{\mathrm{b}}$ & $2009^{\mathrm{b}}$ \\
\hline Pure stand & $692735 \mathrm{a}$ & $3461990 \mathrm{a}$ \\
$\mathrm{CVM}^{\mathrm{c}}$ & $9402 \mathrm{~b}$ & $799818 \mathrm{~b}$ \\
$\mathrm{CVM}+\mathrm{S}^{\mathrm{d}}$ & $2160 \mathrm{~b}$ & $269847 \mathrm{c}$ \\
\hline
\end{tabular}

Means followed by different letters in a column are significantly different $(P=0.05)$ according to the Newman-Keuls test.

a PAD: ascospores per square metre of orchard floor.

b Log-transformed data before ANOVA.

c CVM: cultivar mixture between Melrouge and Pitchounette.

d CVM + S: cultivar mixture between Melrouge and Pitchounette with sanitation practices.

\subsection{Rosy apple aphid}

In 2008, rosy apple aphid damages were less important for Pitchounette cultivar than for Melrouge one. However, in 2009, the same level of rosy apple aphid damages was observed in both cultivars (Table 4). A positive effect of cultivar mixture was observed in 2008 for Melrouge when Pitchounette had a good resistance level (Table 6).

\section{Discussion}

Our results prove the interest of the cultivar mixture (within row mixture, between a partial resistant and a monogenic resistant cultivar) for scab control in our experimental conditions (Riv6 gene not overcome). The cultivar mixture was able to significantly reduce the Potential Ascospore Dose and the incidence on fruits during the two experimental years. In 2009, after placing a net to isolate the $\mathrm{CVM}+\mathrm{S}$ plots, the results showed that the sanitation associated with the cultivar mixture was able to significantly reduce the potential ascospore dose and the incidence and the severity on fruit (compared with cultivar mixture alone).

A reduction of scab incidence on fruits of 38 and $7.3 \%$ was observed at picking in 2008 and 2009 in the CVM plots compared to the pure stand, respectively. Didelot et al. (2007), working in a conventional orchard with a high inoculum, found a significant effect of two cultivar mixtures between a susceptible cultivar (Golden Delicious) and a resistant one, on leaf incidence during shoot growth period. However, they did not observe difference on fruit incidence at picking. In our study, the cultivar mixture was able to reduce significantly the fruit incidence the two years, despite the high level of disease in 2009. This result could be explained by the lower susceptibility of cv. Melrouge compared to Golden, the less favourable climatic conditions in Rhone Valley than in Loire Valley, and also the less favourable environmental conditions for scab in organic orchards than in conventional orchards due to higher planting distances and lower growth.

Another important aim of this work was to assess the association effects of two control methods with partial efficacy. Compared to cultivar mixture alone, the cultivar mixture associated with sanitation practices was able to reduce significantly the scab incidence and severity on fruits in 2009 , when experimental conditions were improved and permitted a good estimation of the effects of sanitation practices. This point seems positive, and confirms the
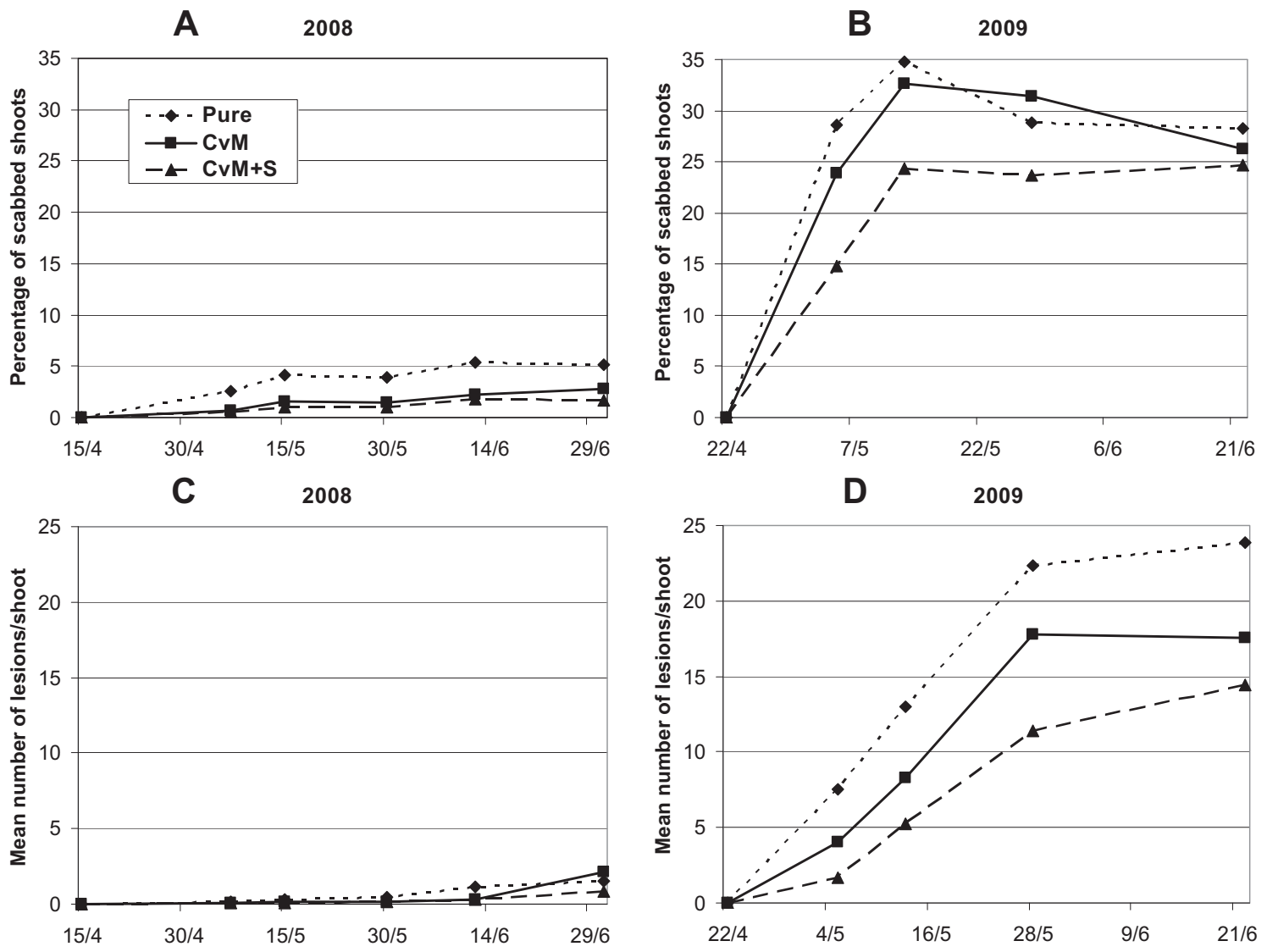

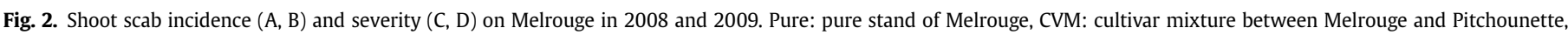
$\mathrm{CVM}+\mathrm{S}$ : cultivar mixture with sanitation practices. 
Version définitive du manuscrit publiée dans / Final version of the manuscript published in :

Crop Protection (2013), Vol. 43, p. 207-212, DOI: 10.1016/j.cropro.2012.09.014

Journal homepage: http://www.elsevier.com/locate/cropro

Table 3

AUDPC of shoot scab incidence, AUDPC of shoot scab severity, fruit scab incidence and fruit scab severity on Melrouge in pure stand of Melrouge and the two cultivar mixtures.

\begin{tabular}{|c|c|c|c|c|c|c|c|c|}
\hline & \multicolumn{2}{|c|}{$\begin{array}{l}\text { AUDPC of shoot } \\
\text { scab incidence }\end{array}$} & \multicolumn{2}{|c|}{$\begin{array}{l}\text { AUDPC of shoot } \\
\text { scab severity }\end{array}$} & \multicolumn{2}{|c|}{$\begin{array}{l}\text { Fruit scab } \\
\text { incidence }\end{array}$} & \multicolumn{2}{|c|}{$\begin{array}{l}\text { Fruit scab } \\
\text { severity }^{b}\end{array}$} \\
\hline & $2008^{c}$ & $2009^{d}$ & $2008^{c}$ & $2009^{d}$ & $2008^{e}$ & 2009 & 2008 & 2009 \\
\hline Pure stand & $274.9 a$ & 1629.2a & $44.3 a$ & $973.5 a$ & $14.9 a$ & $82.2 \mathrm{a}$ & $2.9 a$ & 7.3a \\
\hline $\mathrm{CVM}^{\mathrm{f}}$ & $111.9 \mathrm{~b}$ & $1582.3 a$ & $29.6 a$ & 711.9ab & $9.3 b$ & $76.2 b$ & $2.9 a$ & $6.5 a$ \\
\hline $\mathrm{CVM}+\mathrm{S}^{\mathrm{g}}$ & $79.6 \mathrm{~b}$ & $1218.5 b$ & $17.3 a$ & $486.6 b$ & $7.3 b$ & $70.5 c$ & $2.5 a$ & $4.8 \mathrm{~b}$ \\
\hline
\end{tabular}

Means followed by different letters in a column are significantly different $(P=0.05)$ according to the Newman-Keuls test.

a Percentage of scabbed fruits at picking.

b Number of lesions per scabbed fruit at picking.

c From 15 of April to 1 st of July.

d From 22 of April to 22 of June.

e Log-transformed data before Anova.

f CVM: cultivar mixture between Melrouge and Pitchounette.

g CVM + S: cultivar mixture between Melrouge and Pitchounette with sanitation practices.

hypothesis that this two control methods, acting at two different times of the pathogen cycle, could be associated with success (Didelot et al., 2007). This result supports the hypothesis that this strategy of association could be completed with other control methods (reduced fungicide schedules, elicitors from natural origin applications, both compatible with organic rules). It was not expected to achieve a good control of the disease with cultivar mixture, associated or not with sanitation, without fungicide application, especially in the high inoculum context of the second experimental year. As fungicide applications could enhance the effects of cultivar mixtures (Garrett et al., 2001; Mundt et al., 2002; Didelot et al., 2007) it would be particularly interesting to complete the association strategy with moderate applications of fungicides.

Very few data were available on the effects of cultivar mixtures on the other pests and diseases of apple. Since scab is often a main problem in orchard, it is necessary to know the effects of a strategy to counter the scab infection in a context of whole complex of pests and diseases. Our study permitted to collect results on two other important enemies of apple, powdery mildew and rosy aphid.

For powdery mildew secondary infection, a significant effect of the mixture, at the condition it is associated with sanitation, was observed in case of a moderate level of the disease (2008), but no significant effect was observed when the level of disease was low (2009). These results could be explained by the fact that in case of low infection there is no measurable effect of a method of control. It is difficult to propose more explanation, as several factors influencing the efficacy of cultivar mixtures are unknown for powdery mildew. For example, the pathogenicity on Melrouge and Pitchounette of the P. leucotricha strains present in the experimental orchard was unknown. Two other factors are important: the spatial distribution of initial inoculum, and the steepness of the spore

Table 4

Comparison of the level of powdery mildew and rosy apple aphid susceptibility between Melrouge and Pitchounette in the two cultivar mixtures.

\begin{tabular}{|c|c|c|c|c|}
\hline & \multicolumn{2}{|c|}{$\begin{array}{l}\text { Powdery mildew } \\
\text { secondary infection }^{\text {a }}\end{array}$} & \multicolumn{2}{|c|}{$\begin{array}{l}\text { Rosy apple aphid } \\
\text { incidence }^{b}\end{array}$} \\
\hline & $2008^{c}$ & 2009 & 2008 & 2009 \\
\hline Melrouge & $13.0 \mathrm{a}$ & $6.2 a$ & $17.3 a$ & $21.1 \mathrm{a}$ \\
\hline Pitchounette & $0.3 \mathrm{~b}$ & $0.6 \mathrm{~b}$ & $3.2 \mathrm{~b}$ & $25.0 \mathrm{a}$ \\
\hline
\end{tabular}

Means followed by different letters in a column are significantly different $(P=0.05)$ according to the Newman-Keuls test.

a Percentage of infested leaves with mildew.

b Percentage of infested shoots by rosy aphid.

${ }^{c}$ Log-transformed data before ANOVA.
Table 5

Powdery mildew primary and secondary infections on Melrouge and Pitchounette in the pure stand of Melrouge and the two cultivar mixtures.

\begin{tabular}{|c|c|c|c|c|c|c|c|c|}
\hline & \multicolumn{4}{|c|}{ Primary infection $^{a}$} & \multicolumn{4}{|c|}{ Secondary infection $^{\mathrm{b}}$} \\
\hline & \multicolumn{2}{|c|}{ Melrouge } & \multicolumn{2}{|c|}{ Pitchounette } & \multicolumn{2}{|c|}{ Melrouge } & \multicolumn{2}{|c|}{ Pitchounette } \\
\hline & 2008 & 2009 & 2008 & 2009 & $2008^{c}$ & 2009 & 2008 & 2009 \\
\hline Pure stand & $6.1 \mathrm{a}$ & $0.95 a$ & & & $21.8 \mathrm{a}$ & $5.5 a$ & & \\
\hline $\mathrm{CVM}^{\mathrm{d}}$ & $3.7 a$ & $0.93 a$ & $1.6 a$ & $0.38 a$ & 15.3ab & $7.8 \mathrm{a}$ & $0.3 a$ & $0.7 a$ \\
\hline $\mathrm{CVM}+\mathrm{S}^{\mathrm{e}}$ & $4.0 \mathrm{a}$ & $0.74 a$ & $1.4 \mathrm{a}$ & $0.08 \mathrm{~b}$ & $10.7 b$ & $4.5 a$ & $0.3 a$ & $0.5 a$ \\
\hline
\end{tabular}

Means followed by different letters in a column are significantly different $(P=0.05)$ according to the Newman-Keuls test.

a Number of shoot with mildew per tree.

b Mean percentage of leaves with mildew.

c Log-transformed data before ANOVA.

d CVM: cultivar mixture between Melrouge and Pitchounette.

e CVM + S: cultivar mixture between Melrouge and Pitchounette with sanitation practices.

dispersal gradient $(\mathrm{Xu}, 2011)$. The steepness of the spore dispersal gradient is not known precisely in the case of $P$. leucotricha.

For rosy aphids, the positive effect of mixture cultivar observed in 2008 could be explained by a "resource dilution" effect of a susceptible cultivar (i.e. Melrouge) by a lower susceptible one (i.e. Pitchounette). The cultivar mixture within a row could have an effect on the return flight process (autumn) and/or during rosy aphids development in spring. Studies showed that the number of insect pests found on a Brassica crop was considerably reduced when the crop was undersown with living mulch such as clover, which the authors attributed to the difficulty that the insects had in locating their host plant (Finch and Kienegger, 1997; Finch and Collier, 2000). A similar effect of resource dilution could have occurred in cultivar mixtures and could explain the difference observed in 2008, when Pitchounette had a good resistance level. Pitchounette cultivar has a strong alternate-bearing behaviour whereas Melrouge one is less important. The flowering rate of Pitchounette cultivar was alternately low in 2008 and high in 2009 in the experimental plot. Alternate bearing modifies tree physiology and anatomy, which can modify tree appetence for rosy aphids in autumn.

For mildew and rosy aphid, our study showed that cultivar mixture did not enhance the damages caused by these enemies. For both, a positive effect for the limitation of infection or infestation was observed. These results must be confirmed, but seem positive for the cultivar mixture development in organic orchards, where the control of some pests and diseases is more difficult than in conventional ones. They are in accordance with the results obtained by Cox et al. (2004) and Quénéhervé et al. (2011), which showed respectively the interest of cultivar mixtures for the simultaneous management of multiple diseases, and the effect of

\section{Table 6}

Rosy apple aphid incidence in the pure stand of Melrouge and the two cultivar mixtures.

\begin{tabular}{llllll}
\hline & \multicolumn{3}{l}{ Rosy apple aphid incidence ${ }^{\mathrm{a}}$} \\
\cline { 2 - 3 } & \multicolumn{2}{l}{ Melrouge } & & \multicolumn{2}{l}{ Pitchounette } \\
\cline { 2 - 3 } \cline { 5 - 6 } & 2008 & 2009 & & 2008 & 2009 \\
\hline Pure stand & $34.6 \mathrm{a}$ & $34.6 \mathrm{a}$ & & & \\
$\mathrm{CVM}^{\mathrm{b}}$ & $17.9 \mathrm{~b}$ & $24.4 \mathrm{a}$ & & $3.8 \mathrm{a}$ & $25.6 \mathrm{a}$ \\
$\mathrm{CVM}+\mathrm{S}^{\mathrm{c}}$ & $16.7 \mathrm{~b}$ & $17.9 \mathrm{a}$ & & $2.6 \mathrm{a}$ & $24.4 \mathrm{a}$ \\
\hline
\end{tabular}

Means followed by different letters in a column are significantly different $(P=0.05)$ according to the Newman-Keuls test.

a Percentage of infested shoots.

b CVM: cultivar mixture between Melrouge and Pitchounette.

c $\mathrm{CVM}+\mathrm{S}$ : cultivar mixture between Melrouge and Pitchounette with sanitation practices. 
varietal mixtures on the number and community structure of plant feeding nematodes. They confirm the interest of studying the effects of cultivar mixtures on several pests and diseases of a culture, with the limit that in this case cultivar mixtures must provide multiple differential susceptibilities.

\section{Acknowledgements}

The authors acknowledge student Arnaud Margueritte for participating to this work, carried out with the financial support of the ANR - Agence Nationale de la Recherche - The French National Research Agency under the Programme Agriculture et Développement Durable, project ANR-06-PADD-59000122, GéDuPIC, the French Ministry of Agriculture and the Rhône-Alpes region.

\section{References}

Bousset, L., Blaise, P., Kellerhals, M., Gessler, C., 1997. Mixtures of apple cultivars in orchards: effect on the scab epidemics. IOBC/WPRS Bull. 20, 42-48.

Bus, G.M., Rikkerink, E.H.A., Caffier, V., Durel, C.E., Plummer, K., 2011. Revision of the nomenclature of the differential host-pathogen interactions of Venturia inaequalis and Malus. Annu. Rev. Phytopathol. 49, 391-413.

Brun, L., Didelot, F., Parisi, L., 2008. Effects of apple cultivar susceptibility to Venturia inaequalis on scab epidemics in apple orchards. Crop Prot. 27, 1009-1019.

Brun, L., Gros, C., Combe, F., Parisi, L. Relationships between Venturia inaequalis potential ascospore dose, aerial ascospore concentration, climatic risks and scab development; effects on experimental designs. IOBC/WPRS Bulletin, in press.

Brun, L., Guinaudeau, J., Gros, C., Parisi, L., Simon, S., 2010. Assessment of fungicide protection strategies in experimental apple orchards. IOBC/WPRS Bull. 54, 103107.

Caffier, V., Didelot, F., Orain, G., Lemarquand, A., Parisi, L., 2010. Efficiency of association of scab control methods on resistance durability on apple: the case study of cultivar Ariane. IOBC/WPRS Bull. 5, 327-330.

Carisse, O., Ordon, V., Philion, V., Paulitz, T., 1997. Evaluation of fungal antagonists for the reduction of ascospore potential of Venturia inaequalis. IOBC/WPRS Bull. 20, 56-63.

Carisse, O., Philion, V., Rolland, D., Bernier, J., 2000. Effect of fall application of fungal antagonists on spring ascospore production of the apple scab pathogen, Venturia inaequalis. Phytopathology 90, 31-37.

Combe, F., Mercier, V., Brun, L., 2005. Trois nouvelles variétés de pommier résistantes à la tavelure: intérêt en protection intégrée. Phytoma - La défense des végétaux 581, 12-14.

Cox, C.M., Garrett, K.A., Bowden, R.L., Fritz, A.K., Dendy, S.P., Heer, W.F., 2004. Cultivar mixtures for the simultaneous management of multiple diseases: tan spot and leaf rust on wheat. Phytopathology 94, 961-969.

Dagnélie, P., 1975. Théorie et methodes statistiques, vol. 2. Les presses agronomiques de Gembloux, Gembloux.

Didelot, F., Brun, L., Parisi, L., 2007. Effects of cultivar mixtures on scab control in apple orchards. Plant Pathol. 56, 1014-1022.

Didelot, F., Caffier, V., Baudin, M., Orain, G., Lemarquand, A., Parisi, L., 2010. Integrating scab control methods with partial effects in apple orchards: the association of cultivar resistance, sanitation and reduced fungicide schedules. IOBC/ WPRS Bull. 54, 525-528.

Didelot, F., Parisi, L., Orain, G., Lemarquand, A., Le Cam, B., Laurens, F., Caffier, V., 2009. Situation actuelle en France du contournement de la résistance $V f$ par Venturia inaequalis-propositions de méthodes de lutte adaptées. Comptesrendus des Journées Technique Nationales Fruits \& Légumes Biologiques, 8 et 9 décembre 2009, Paris, pp. 65-68.
Finch, S., Collier, R.H., 2000. Host-plant selection by insects - a theory based on appropriate/inappropriate landings' by pests insects of cruciferous plants. Entomol. Exp. Appl. 96, 91-102.

Finch, S., Kienegger, M., 1997. A behavioural study to help clarify how undersowing with clover affects host plant selection by pests insects of brassica crops. Entomol. Exp. Appl. 84, 165-172.

Gadoury, D.M., Mac Hardy, W.E., 1986. Forecasting ascopore dose of Venturia inaequalis in commercial apple orchards. Phytopathology 76, 112-118.

Garrett, K.A., Nelson, R.J., Mundt, C.C., Chacón, G., Jaramillo, R.E., Forbes, G.A., 2001. The effects of host diversity and other management components on epidemics of potato late blight in the humid highland tropics. Phytopathology 91, 993-1000.

Gomez, C., Brun, L., Chauffour, D., De Le Vallée, D., 2007. Effect of leaf litter management on scab development in an organic apple orchard. Agric. Ecosyst. Environ. 118, 249-255.

MacDonald, B.A., Linde, C., 2002. Pathogen population genetics, evolutionary potential and durable resistance. Annu. Rev. Phytopathol. 40, 349-379.

McCracken, A.R., Dawson, W.M., 2003. Rust disease (Melampsora epitea) of willow (Salix spp.) grown as short rotation coppice (SRC) in inter- and intra-species mixtures. Ann. Appl. Biol. 143, 381-393.

Mills, W.D., Laplante, A.A., 1951. Diseases and insects in the orchard. Cornell Ext. Bull. 711

Moreno Ruiz, G., Castillo Zapata, J., 1990. The Variety Columbia: a Variety of Coffee with Resistance to Rust (Hemileia vastatrix Berk. \& Br.), Chinchina-Caldas, Columbia. In: Cenicafe Publication No. 9 (Technical Bulletin). Subgerencia General Tecnica Centro Nocional De Investigations de Cafe.

Mundt, C.C., 2002. Use of multiline cultivars and cultivar mixtures for disease management. Annu. Rev. Phytopathol. 40, 381-410.

Mundt, C.C., Cowger, C., Garrett, K.A., 2002. Relevance of integrated disease management to resistance durability. Euphytica 124, 245-252.

Olivier, J.M., 1986. La tavelure du pommier, conduite d'une protection raisonnée. Adalia 1, 3-19.

Parisi, L., Laurens, F., Didelot, F., Evans, K., Fischer, C., Fouillet, V., Gennari, F. Kemp, H., Lateur, M., Patocchi, A., Schouten, H.J., Tsipouridis, C., 2006 Geographical distribution of Venturia inaequalis strains virulent to the Vf gene in Europe. IOBC/WPRS Bull. 29, 49-52.

Quénéhervé, P., Barrière, V., Salmon, F., Houdin, F., Achard, R., Gertrude, J.C., MarieLuce, S., Chabrier, C., Duyck, P.F., Tixier, P., 2011. Effect of banana crop mixtures on the plant-feeding nematode community. Appl. Soil Ecol. 49, 40-45.

R Development Core Team, 2009. R: a Language and Environment for Statistical Computing. R Foundation for Statistical Computing, Vienna, Austria.

Simon, S., Lauri, P.E., Brun, L., Defrance, H., Sauphanor, B., 2006. Does manipulation of fruit-tree architecture affect the development of pests and pathogens? A case study in an organic apple orchard. J. Hortic. Sci. Biotechnol. 81, 765-773.

Sutton, D.K., MacHardy, W.E., Lord, W.G., 2000. Effect of shredding or treating apple leaf litter with urea on ascospore dose of Venturia inaequalis and disease buildup. Plant Dis. 84, 1319-1326.

Trapman, M., 2006. Resistance management in $V f$ apple scab resistant organic apple orchards. In: Boos, Markus (Ed.), Eco-fruit: Proceedings of the 12th International Conference on Cultivation Technique and Phytopathological Problems in Organic Fruit-growing. Fördergemeinschaft Ökologischer Obstbau e.V. (FÖKO), Weinsberg, Germany, pp. 108-112.

Trillot, M., Masseron, A., Mathieu, V., Bergougnoux, F., Hutin, C., 2002. Le pommier. CTIFL, Paris.

Vincent, C., Rancourt, B., Carisse, O., 2004. Apple leaf shredding as a non-chemical tool to manage apple scab and spotted tentiform leafminer. Agric. Ecosyst. Environ. 104, 595-604.

Wolfe, M.S., 1985. The current status and prospects of multiline cultivars and variety mixtures for disease resistance. Annu. Rev. Phytopathol. 23, 251-273.

Xu, X.-M., 2011. A simulation study on managing plant diseases by systematically altering spatial positions of cultivar mixture components between seasons. Plant Pathol. 60, 857-865.

Zhu, Y.Y., Chen, H.R., Fan, J.H., Wang, Y.Y., Li, Y., Chen, J.B., Fan, J.X., Yang, S.S., Hu, L.P., Leung, H., Mew, T.W., Teng, P.S., Wang, Z., Mundt, C.C., 2000. Genetic diversity and disease control in rice. Nature 406, 718-722. 